\title{
THE KINETICS OF SMALL-IMPURITY \\ GRAIN-BOUNDARY-SEGREGATION FORMATION IN COLD-ROLLED DEEP-DRAWING 08C-Al AND IF STEELS DURING POST-DEFORMATION ANNEALING
}

\author{
KINETIKA NASTANKA SEGREGACIJE NEČISTOČ PO MEJAH \\ ZRN MED ŽARJENJEM PO HLADNEM VALJANJU JEKEL 08C-Al \\ IN IF ZA GLOBOKI VLEK
}

\author{
Alexander Rashkovskiy, Anatoly Kovalev, Dmitry Wainstein, Irina Rodionova, \\ Yulia Bykova, Diana Zakharova \\ I. P. Bardin Central Research Institute for Ferrous Metallurgy "CNIICHERMET", Radio str. 23/9, build. 2, off. 475, 105005 Moscow, Russian \\ Federation \\ a_rashkovskiy@sprg.ru
}

Prejem rokopisa - received: 2014-07-31; sprejem za objavo - accepted for publication: 2014-09-19

\begin{abstract}
An investigation of small-impurity grain-boundary-segregation (GBS) kinetics in deep-drawing steels (DDSs) allows us to improve the mechanical properties of these steels by optimizing the post-deformation heat-treatment parameters. The kinetics of the GBS formation for C, N, P and S was determined with a series of isothermal expositions of specimens in the spectrometer work chamber at temperatures of $250-650{ }^{\circ} \mathrm{C}$. The surface chemical composition of the samples was measured with Auger electron spectroscopy (AES). Isodose C-curves of the GBS for each detected impurity were plotted. The time - temperature intervals of the preferential GB enrichment with $\mathrm{C}, \mathrm{N}, \mathrm{P}, \mathrm{S}$ were determined for the $08 \mathrm{C}-\mathrm{Al}$ steel with various reduction ratios and for the IF-steels with various concentrations of the micro-alloying elements $\mathrm{Nb}$ and Ti. It was found that cold rolling of the $08 \mathrm{C}$-Al steel with a reduction ratio from $48 \%$ to $80 \%$ dramatically increases the preferential carbon GBS temperature from 350 ${ }^{\circ} \mathrm{C}$ to $450{ }^{\circ} \mathrm{C}$ due to the necessity of the carbon detachment from Cottrell atmospheres with the annealing of dislocations. The influence of the IF-steel micro-alloying with $\mathrm{Nb}$ and $\mathrm{Ti}$ on the concurrent multicomponent GBS of interstitial and substitution impurities is also demonstrated in the article.

Keywords: deep-drawing steels, IF-steels, grain-boundary segregation, Auger electron spectroscopy, annealing, dislocation structure, microalloying

Preiskava kinetike segregacije nečistoč po mejah zrn (GBS) v jeklih za globoki vlek (DDS) omogoča izboljšanje mehanskih lastnosti teh jekel z optimizacijo parametrov toplotne obdelave po hladni deformaciji. Kinetika nastanka GBS za C, N, P in S je bila določena s serijo izotermne izpostavitve vzorcev v delovni komori spektrometra pri temperaturah $250-650{ }^{\circ} \mathrm{C}$. Kemijska sestava površine je bila izmerjena z Augerjevo elektronsko spektroskopijo (AES). Narisane so bile krivulje enakih odmerkov C za GBS za vsako odkrito nečistočo. Intervali čas - temperatura preferenčnih GB-obogatitev C, N, P, S so bili določeni za $08 \mathrm{C}-\mathrm{Al}$ jeklo pri različnih stopnjah redukcije in za IF-jekla $\mathrm{z}$ različnimi koncentracijami mikrolegirnih elementov $\mathrm{Nb}$ in Ti. Ugotovljeno je, da pri hladnem valjanju 08C-Al-jekla s stopnjo redukcije med $48 \%$ in $80 \%$ naraste preferenčna temperatura GBC ogljika iz $350{ }^{\circ} \mathrm{C}$ na $450{ }^{\circ} \mathrm{C}$ zaradi potrebe razdvojitve ogljika iz Cottrellovega oblaka z žarjenjem dislokacij. V članku je prikazan tudi vpliv mikrolegiranja z Nb in Ti v IF-jeklu na sočasno večkomponentno GBS intersticijskih in substitucijskih nečistoč.

Ključne besede: jekla za globoki vlek, IF-jekla, segregacije po mejah zrn, Augerjeva elektronska spektroskopija, žarjenje, struktura dislokacij, mikrolegiranje
\end{abstract}

\section{INTRODUCTION}

The modern automotive industry increasingly demands the drawability of steels due to the necessity to decrease the weight of the car by thinning its body parts and due to the current fashions for the exterior of the car. The forming of rolled sheets with reduction ratios of up to $80 \%$ requires a very high technological plasticity after heat treatment.

The mechanical properties of deep-drawing steels (DDS) are determined by the micro- and nanostructured parameters, such as the size and shape of grains, the texture, the concentration of the non-metallic inclusions, the dislocation structure and the perfection of the grain boundaries. The necessary structure and composition of grain boundaries may be achieved by varying the postdeformation-annealing (PDA) regimes. That is why the PDA is the most critical stage of DDS production.

Multicomponent grain-boundary segregation (GBS) in steels is a concurrent process controlled by the thermodynamic and kinetic factors. ${ }^{1}$ Each impurity $(\mathrm{C}, \mathrm{N}, \mathrm{P}$, $\mathrm{S}$, etc.) in a solid solution has its own time-temperature interval for the preferential enrichment of a GB. Typically, $\mathrm{C}$ and $\mathrm{N}$, as the most mobile elements in steel, form GB segregations at temperatures of about 300-350 ${ }^{\circ} \mathrm{C} .{ }^{2}$ Other elements such as P, S, As, Sn and their analogues usually reach the GBs at higher temperatures. This phenomenon is exhibited by the most mobile impu- 
Table 1: Chemical composition of $08 \mathrm{C}$-Al steels in mass fractions, $w / \%$

Tabela 1: Kemijska sestava jekla 08C-Al v masnih deležih, w/\%

\begin{tabular}{|c|c|c|c|c|c|c|c|c|c|c|c|c|c|c|}
\hline Melt \# & $\mathrm{C}$ & $\mathrm{Si}$ & $\mathrm{Mn}$ & $\mathrm{P}$ & $\mathrm{S}$ & $\mathrm{Cr}$ & $\mathrm{Ni}$ & $\mathrm{Mo}$ & $\mathrm{Cu}$ & $\mathrm{Al}$ & $\mathrm{N}$ & $\mathrm{V}$ & $\mathrm{Ti}$ & $\mathrm{Nb}$ \\
\hline 1 & 0.04 & 0.01 & 0.15 & 0.008 & 0.016 & 0.02 & 0.02 & 0.002 & 0.04 & 0.04 & 0.004 & 0.002 & 0.001 & 0.002 \\
\hline 2 & 0.045 & 0.009 & 0.17 & 0.012 & 0.0186 & 0.030 & 0.025 & 0.005 & 0.035 & 0.039 & 0.0025 & 0.002 & - & - \\
\hline
\end{tabular}

rities ( $\mathrm{C}$ and $\mathrm{N}$ ) migrating to grain boundaries, causing a decrease in the free energy of the GB. The elements of $\mathrm{C}$ and $\mathrm{N}$ occupying the possible sites at the interfaces at low temperatures prevent a further migration of any other elements to the GB from the solid solution (the grain volume). It was shown that the interstitial $(\mathrm{C}, \mathrm{N}, \mathrm{B})$ and substitutional $(\mathrm{P}, \mathrm{S}$, etc.) atoms occupy different places at a GB. ${ }^{3}$ The $\mathrm{C}$ and $\mathrm{N}$ in the solid solution $(\alpha-\mathrm{Fe})$ in steels act as good surfactants with a high diffusion-mobility control of the behavior of other impurities.

The phosphorus in steel is a very strong surfactant element. Under favorable conditions it can enrich the GBs thousands of times compared to its bulk concentration. DDS and, especially, IF-steels contain very low amounts of carbon and other impurities (typically tens of ppm). When phosphorus adsorbs on the grain boundaries, it significantly decreases the cohesion of the grains and, correspondingly, reduces the damage resistance of the steel. So, we had to pay special attention to the $\mathrm{P}$ behavior during the DDS annealing relative to the $\mathrm{C}$ and $\mathrm{N}$ concentrations in the solid solution and the reduction ratios after cold rolling in the IF and $08 \mathrm{C}$ - $\mathrm{Al}$ steels for the maximum drawability grades of CR4 and CR5. ${ }^{4}$

\section{MATERIALS AND METHODS}

Four samples of cold-rolled 08C-Al steels (Table 1) with various reduction ratios (Table 2) and three samples of hot-rolled IF-steels (Table 3) with various $\mathrm{Ti}$ and $\mathrm{Nb}$ contents were investigated.

Table 2: Reduction ratio of $08 \mathrm{C}-\mathrm{Al}$ samples

Tabela 2: Stopnje redukcije vzorcev 08C-Al

\begin{tabular}{|c|c|c|}
\hline Melt & Sample & $\varepsilon_{\text {c.r. }} / \%$ \\
\hline \multirow{3}{*}{1} & $1-1$ & 48 \\
\cline { 2 - 3 } & $1-2$ & 58 \\
\cline { 2 - 3 } & $1-3$ & 78 \\
\hline 2 & $2-4$ & 80 \\
\hline
\end{tabular}

Table 3: Measured and required content of $\mathrm{Ti}$ and $\mathrm{Nb}$ in the investigated IF-steels

Tabela 3: Izmerjena in zahtevana vsebnost $\mathrm{Ti}$ in $\mathrm{Nb}$ v preiskovanih IF-jeklih

\begin{tabular}{|c|c|c|c|c|c|c|}
\hline $\begin{array}{c}\text { Sample } \\
\#\end{array}$ & $\begin{array}{c}\text { Ti in } \\
\text { steel } \\
(w / \%)\end{array}$ & $\begin{array}{c}\text { Ti req. } \\
(w / \%)\end{array}$ & $\begin{array}{c}\text { Nb in } \\
\text { steel } \\
(w / \%)\end{array}$ & $\begin{array}{c}\text { Nb req. } \\
(w / \%)\end{array}$ & $\begin{array}{c}\mathrm{P} \\
(w / \%)\end{array}$ & $\begin{array}{c}\mathrm{S} \\
(w / \%)\end{array}$ \\
\hline $3-1$ & 0.029 & 0.0432 & 0.031 & 0.050 & $\approx 0.005$ & $\approx 0.005$ \\
\hline $3-2$ & 0.068 & 0.039 & 0.002 & 0.007 & 0.007 & 0.004 \\
\hline $3-3$ & 0.071 & 0.038 & 0.025 & 0.024 & 0.009 & 0.008 \\
\hline
\end{tabular}

GBS processes are typically studied on the clean surfaces of heat-treated samples fractured in a vacuum. As the steels under investigation had a very high plasticity, together with a thickness after rolling of less than 1.2 $\mathrm{mm}$, it was impossible to achieve a well-expressed brittle fracture, even at $-196{ }^{\circ} \mathrm{C}$. So, we used a simulation of GBS kinetics segregation on a free surface of thin $(0.1$ $\mathrm{mm}$ ) flat samples. This approach gives adequate results for the qualitative studies of isothermal segregation kine$\operatorname{tics}^{5,6}$ when we do not need to precisely determine the segregation energies.

Multicomponent GBS kinetics was studied by annealing the samples one by one in an ESCALAB MK2 (VG, UK) spectrometer work chamber under UHV $\left(10^{-8}\right.$ $\mathrm{Pa}$ ) at constant temperatures from $250{ }^{\circ} \mathrm{C}$ to $550{ }^{\circ} \mathrm{C}$ with a step of about $50{ }^{\circ} \mathrm{C}$. The chemical composition of the surface was measured with Auger electron spectroscopy (AES) every 5-7 min. Then the isothermal $C(t)$ curves for all the annealing temperatures were plotted and sectioned at the characteristic concentrations to obtain the isodose $T(t) \mathrm{C}$-curves for the $\mathrm{C}, \mathrm{N}$ and $\mathrm{P}$ segregation. The sample surfaces were cleaned with $\mathrm{Ar}^{+}$ions before the AES measurements.

An example of the AES spectra acquired from a DDS sample surface is shown in Figure 1. One can clearly see that after the annealing of sample $3-2$ at $560{ }^{\circ} \mathrm{C}$ for 60 min, the content of $\mathrm{P}$ on the surface is very noticeable. Similar spectra were obtained for all the investigated samples and annealings.

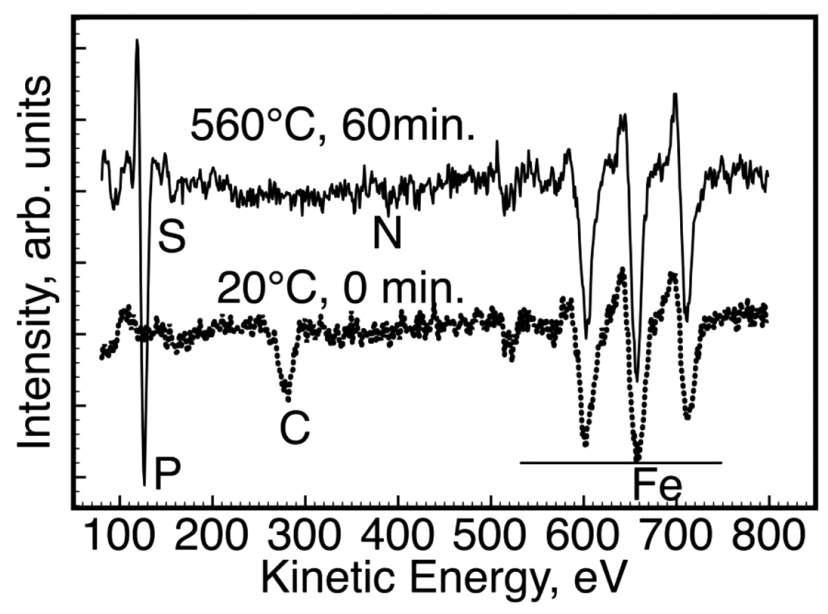

Figure 1: AES spectra of IF-steel before (bottom curve) and after (top curve) the tempering at $560{ }^{\circ} \mathrm{C}$ for $60 \mathrm{~min}$

Slika 1: AES-spekter jekla IF pred žarjenjem 60 min pri $560{ }^{\circ} \mathrm{C}$ (spodnja krivulja) in po njem (zgornja krivulja) 


\section{RESULTS AND DISCUSSION}

\subsection{Influence of the degree of plastic deformation and structurally free carbon mobility on the trace-impu- rity segregation kinetics in DDS $08 C$-Al steels}

An analysis of the carbon-segregation kinetics (Figure 2a) in dependence of the plastic-deformation degree for the samples of $08 \mathrm{C}$-Al steel is demonstrated in Figure $\mathbf{2 b}$. The temperature of the carbon segregation peak is shifted to higher values with the increasing plastic deformation degree. At a reduction ratio of $48 \%$ (sample 1-1) the carbon segregation mostly occurs at $350{ }^{\circ} \mathrm{C}$. At higher reduction ratios of $58 \%$ (sample 1-2) and $74 \%$ (sample 1-3) the maximum carbon GBS at $300-350{ }^{\circ} \mathrm{C}$ is suppressed. The plots in Figure 2a for $80 \%$ (sample $2-4$ ) of the $08 \mathrm{C}$-Al steel reduction ratios were found at $400{ }^{\circ} \mathrm{C}$ ratio demonstrate that $\mathrm{C}$ and $450{ }^{\circ} \mathrm{C}$ correspondingly (Figure 2a). $\mathrm{C}$ and $\mathrm{P}$ are the antagonistic elements and the segregation of carbon at $410-440{ }^{\circ} \mathrm{C}$ suppresses the segregation of $\mathrm{P}$. The dissolution of carbon GBS at the temperatures higher than the upper peak makes the segregation of $\mathrm{P}$ possible.

The maximum carbon concentrations for the $80 \%$ reduction ratio were found at $360{ }^{\circ} \mathrm{C}$ and $440{ }^{\circ} \mathrm{C}$ (Figure
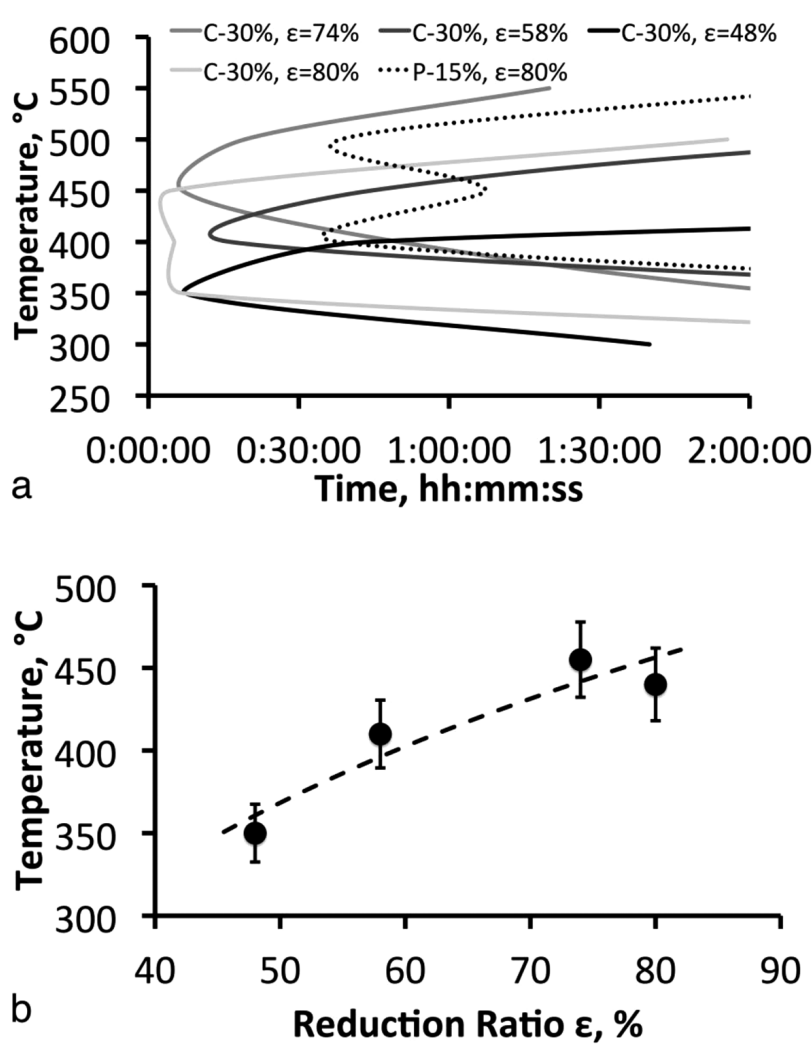

Figure 2: a) Isodose diagram of isothermal segregation of $\mathrm{C}$ and $\mathrm{P}$ in 08C-Al steel with various reduction ratios, b) temperature of the most rapid segregation of $\mathrm{C}$ (C-curve peak nose) versus the reduction ratio after cold rolling

Slika 2: a) Diagram enakih odmerkov izotermnega izcejanja $\mathrm{C}$ in $\mathrm{P}$ v jeklu 08C-Al z različnimi stopnjami redukcije, b) temperatura najhitrejšega izcejanja C (vrh nosa krivulje C) v odvisnosti od stopnje redukcije po hladnem valjanju 2a). The annealing at temperatures higher than the upper peak dissolves the $\mathrm{C}$ segregation, vacating the grain boundaries for the other impurity migration (e.g., P). Such concurrent behavior of various impurity GBSs arises from the kinetic and thermodynamic factors.

On the one hand, the GBS kinetics of any element is closely connected to its concentration and mobility in a solid solution (the grain volume), while carbon, as a good surfactant with the highest diffusion coefficient in $\alpha-\mathrm{Fe}$, controls the GBS of the other elements. On the other hand, increasing the cold-plastic-deformation degree provides the growth of the dislocations density and the concentration of other crystalline lattice defects. Since carbon atoms could be captured in Cottrell atmospheres the dislocations and grain boundaries become the concurrent sites for element binding. The dislocations have a preference due to the higher concentration and the shorter diffusion paths for the carbon atoms to reach the free site. So, the higher dislocation density (plastic deformation degree) the higher the amount of dissolved carbon in $\alpha$-Fe is blocked in these traps. The concentration of mobile carbon atoms in the solid solution becomes lower, and its GBS is suppressed. The detachment of the element from the dislocation traps requires excessive energy and/or a decreasing of the concentration of the traps.

Annealing of the dislocations is a way to release the carbon atoms from Cottrell's atmospheres and prevent the GBS segregation of harmful impurities. However, the time and temperature of the annealing should be adjusted according to the reduction ratio of the DDS rolled sheet.

\subsection{Influence of the concentration of carbide- and nitride-forming elements $(\mathrm{Ti}, \mathrm{Nb})$ on the trace im- purities segregation kinetics in IF-steels}

Due to the strong dependence of the segregation kinetics from cold plastic deformation degree we took the samples of IF-steels after hot rolling due to the more equilibrium state of the micro- and nanostructure.

Typically, IF-steels are alloyed with carbide- and nitride-forming elements: $\mathrm{Ti}$ and $\mathrm{Nb}$. These elements should block the migration of the carbon and nitrogen to the GB. The authors ${ }^{7,8}$ offer equations for a calculation of the required amount of $\mathrm{Ti}$ and $\mathrm{Nb}$ to stabilize the interstitials in IF steels:

$$
\mathrm{Ti}=4 \mathrm{C}+3.42 \mathrm{~N}+1.5 \mathrm{~S}
$$

while the optimal $\mathrm{Nb}$ content is:

$$
\mathrm{Nb}=(7.75 \mathrm{Ti}-3.42 \mathrm{~N}-1.5 \mathrm{~S}) / 4
$$

Table 3 shows the correspondence between the investigated IF-steel's chemical composition and the Ti and $\mathrm{Nb}$ alloying requirements for capturing the structural-free carbon and nitrogen.

We investigated three examples of $\mathrm{Ti}$ and $\mathrm{Nb}$ content (Table 3): Sample 3-1 - insufficient concentration of both $\mathrm{Ti}$ and $\mathrm{Nb}$; Sample 3-2 - shortage of Nb; Sample 
3-3 - concentrations of $\mathrm{Ti}$ and $\mathrm{Nb}$ that are sufficient to extract the carbon and nitrogen from the solid solution. These suggestions were based on the above equations.

Figure 3a represents the C-curves of the carbon and nitrogen segregation in Sample 3-1 (Table 3). There is significant amount of free $\mathrm{C}$ in this sample, and it segregates to the grain boundaries at $250-400{ }^{\circ} \mathrm{C}$. This temperature range includes the non-stable segregation region stipulated by concurrent nitrogen GBS. Both $\mathrm{C}$ and $\mathrm{N}$ are occupying the interstitial positions at interfaces replacing each other. This process develops at $350-400{ }^{\circ} \mathrm{C}$ during the first $30 \mathrm{~min}$ of annealing. The carbon segregation is stable below $300{ }^{\circ} \mathrm{C}$ and the exposition times are less than $30 \mathrm{~min}$. The nitrogen GBS is not stable below $300{ }^{\circ} \mathrm{C}$ and above $400{ }^{\circ} \mathrm{C}$, and dissolves after 30-45 min of isothermal exposition. The maximum nitrogen concentration was found at $450{ }^{\circ} \mathrm{C}$ after $15 \mathrm{~min}$ of annealing. Obviously, the amount of carbide- and nitride-forming elements in this sample (3-1) was insufficient to remove the interstitials from the solid solution and prevent their GBS.

Active phosphorus GBS was formed at temperatures above $400{ }^{\circ} \mathrm{C}$, and it was dissolved above $550{ }^{\circ} \mathrm{C}$. The inhibition of this segregation activity near $450{ }^{\circ} \mathrm{C}$ was stipulated by the active nitrogen migration to the GB. At $450-550{ }^{\circ} \mathrm{C}$ the nitrogen leaves the GB due to the more energy-efficient $\mathrm{P}$ segregation.

In the hot-rolled sample 3-2 no segregation of carbon was found, even after $90 \mathrm{~min}$ of annealing. There was found some GBS of nitrogen (Figure 3b), so there was
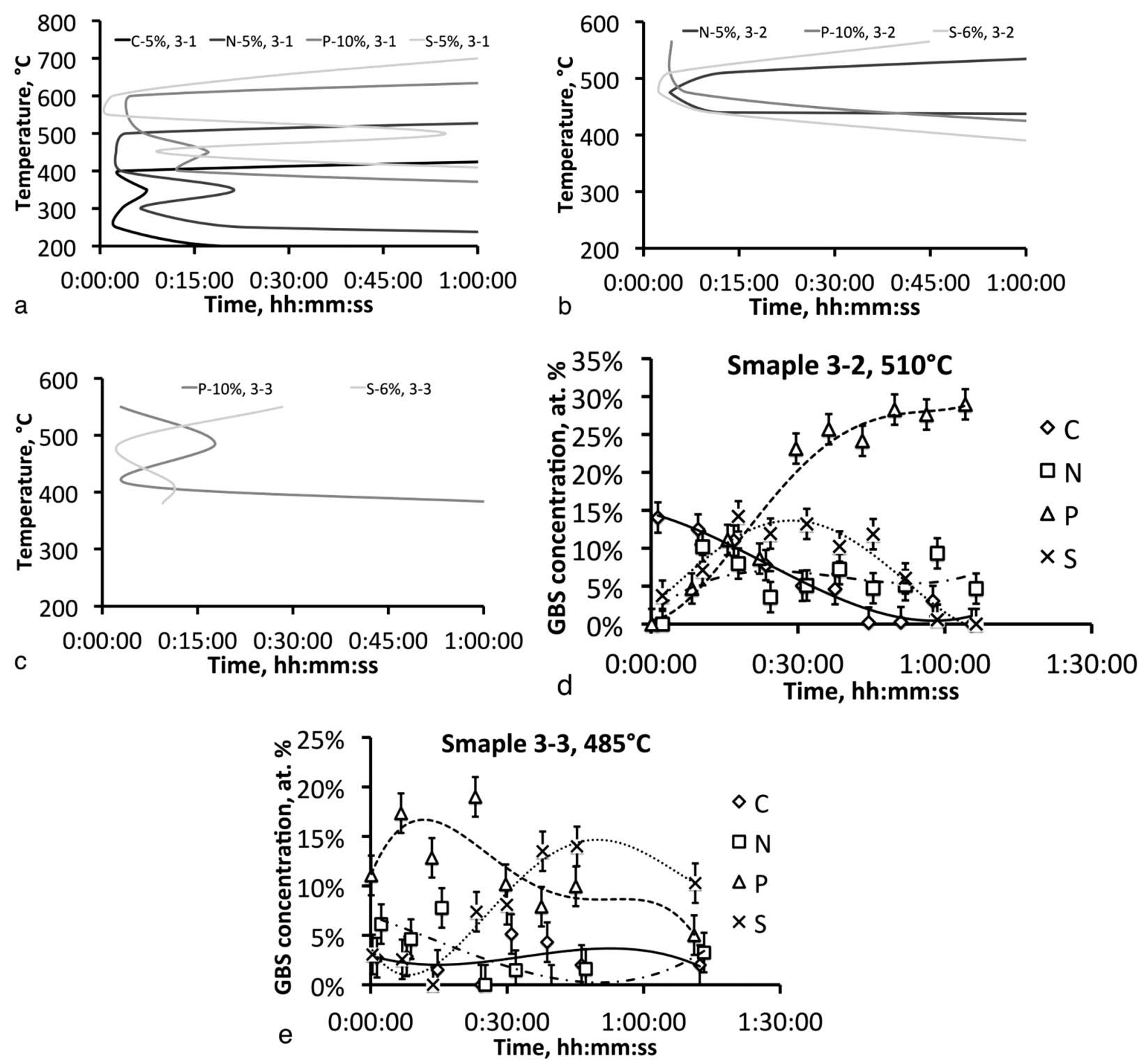

Figure 3: Concurrence between carbon, nitrogen, phosphorus and sulfur GBS in samples: a) 3-1, b) 3-2 and c) 3-3 of IF-steel, d), e) - diagrams of isotermal GBS formation for C, N, P and S for marked temperatures and samples

Slika 3: Ujemanje med GBS ogljika, dušika, fosforja in žvepla v vzorcih: a) 3-1, b) 3-2 in c) 3-3 v IF-jeklu, d), e) - diagrama nastanka izotermne GBS za C, N, P in S za označene temperature in vzorce 
some nitrogen in the solid solution. Its concentration was about $5 \%$ after annealing at $370{ }^{\circ} \mathrm{C}$ for $40 \mathrm{~min}$. The same value was measured at $440{ }^{\circ} \mathrm{C}$ after $20 \mathrm{~min}$. A maximum nitrogen concentration of $10 \%$ was observed in this sample after annealing at $440{ }^{\circ} \mathrm{C}$ for $1 \mathrm{~h}$. The nitrogen GBSs were stable up to $510{ }^{\circ} \mathrm{C}$ and they were dissolved after annealing for $30 \mathrm{~min}$, even at $530{ }^{\circ} \mathrm{C}$.

Below $440{ }^{\circ} \mathrm{C}$ all possible positions at the $\mathrm{GB}$ are occupied by nitrogen atoms, and no other impurities could migrate there. Figure $\mathbf{3 d}$ demonstrates that $\mathrm{P}$ and $\mathrm{S}$ are segregating in concurrence at temperatures above $370{ }^{\circ} \mathrm{C}$. The range of preferential sulfur GBS is from 440 ${ }^{\circ} \mathrm{C}$ to $510{ }^{\circ} \mathrm{C}$. Significant enrichment of the GB by P was observed above $480{ }^{\circ} \mathrm{C}$ (Figure 3d).

It was found that in spite of the higher $\mathrm{P}$ and $\mathrm{S}$ content in Sample 3-3 of hot-rolled IF-steel the optimal alloying with $\mathrm{Ti}$ and $\mathrm{Nb}$ does not only prevent $\mathrm{C}$ and $\mathrm{N}$ GBS, but it also restricts sulfur segregation. It was at the same level as in Sample 3-2. A comparison of Figures $\mathbf{3 b}$ and 3c shows that only phosphorus behavior during the GBS process significantly differs in Sample 3-3. The maximum concentration of $\mathrm{P}$ at the $\mathrm{GB}$ of about $50 \%$ was determined after annealing at $553{ }^{\circ} \mathrm{C}$ for $20 \mathrm{~min}$. It means that such alloying of the IF-steel provides a similar degree of sulfur tiding, both in Samples 3-2 and 3-3, despite the two times higher sulfur content in Sample 3-3 (Table 3). The minimum sulfur GBS formation time (peak of C-curve) was determined at $485{ }^{\circ} \mathrm{C}$ (Figure 3e). The concurrence between $\mathrm{P}$ and $\mathrm{S}$ leads to a gap appearing at the isodose curve of $\mathrm{P}$ (Figure 3c) near this temperature. The phosphorus has two minimum segregation times, near $430{ }^{\circ} \mathrm{C}$ and above $550{ }^{\circ} \mathrm{C}$. It escalates regularly in the absence of nitrogen and carbon segregation (lower peak), and dissolving of the sulfur at higher temperatures.

\section{CONCLUSIONS}

1. Mobile carbon controls the kinetics of the harmful impurities' (P, S) grain-boundary segregation in DDS steels by both thermodynamic (energy) and concurrence (diffusion) mechanisms.

2. Plastic deformation increases the dislocation density, providing capture provides the formation of carbon atoms in Cottrell's atmospheres, decreasing the amount of mobile carbon in $\alpha$-Fe. The temperature of carbon GBS formation shifts to higher values by 50-150 ${ }^{\circ} \mathrm{C}$ depending on the plastic deformation degree due to the concurrence between the dislocation and the grain-boundaries systems.

3. In IF-steels with a low impurities content the GBS of $\mathrm{P}$ and $\mathrm{S}$ has a double-humped isodose segregation curve. It is stipulated by the following factors:

- Preventing carbon and nitrogen GBS formation in the low-temperature range by its binding in $\mathrm{Nb}(\mathrm{CN})$ and $\mathrm{Ti}(\mathrm{CN})$. This facilitates the $\mathrm{P}$ and $\mathrm{S}$ migration to clean grain boundaries.

- Annealing at $500-600{ }^{\circ} \mathrm{C}$ leads to the dissolution of $\mathrm{P}$ and $\mathrm{S}$ segregations.

The optimization of the microalloying and postdeformation annealing parameters for the DDS steels should take into account the multicomponent grainboundary-segregation processes.

\section{Acknowledgements}

This research was partially supported by RFBR research project No. 13-02-12087 ofi_m, RSF research project No. 14-12-00170, and Russian Federation President Scholarship \#2040.2012.1.

\section{REFERENCES}

${ }^{1}$ M. Guttmann, Journal De Physique, IV (1995) 5, 85-96, doi:10.1051/jp4:1995707

${ }^{2}$ W. T. Nachtrab, Y. T. Chou, Met. Trans. A, 17 (1985) 11, 1995-2006, doi:10.1007/BF02644997

${ }^{3}$ A. I. Kovalev, V. P. Mishina, G. V. Stsherbedinsky, D. L. Wainstein, Vacuum, 41 (1990) 7-9, 1794-1795, doi:10.1016/0042-207X(90) 94094-7

${ }^{4}$ ISO 3574:2012, Cold-reduced carbon steel sheet of commercial and drawing qualities, 2012

${ }^{5}$ F. Bezuidenhout, J. Du Plessis, P. E. Viljgen, Surface Science, 171 (1986), 392-399, doi:10.1016/0039-6028(86)91088-5

${ }^{6}$ H. De Rugy, H. Viefhaus, Surface Science, 173 (1986), 418-438, doi:10.1016/0039-6028(86)90200-1

${ }^{7}$ C. Capdevila, V. Amigo, F. G. Caballero, C. Garcia de Andres, M. D. Salvador, Materials Transactions, 51 (2010) 4, 625-634, doi:10.2320/matertrans.MG200909

${ }^{8}$ M. Hua, C. I. Garcia, A. J. De Ardo, Scr. Metall. Mater., 28 (1993), 973-978, doi:10.1016/0956-716X(93)90066-2 